\title{
Stimulation of maternal anti-lymphocyte antibodies by first gestation bovine fetuses
}

\author{
M. J. Newman and H. C. Hines \\ Department of Dairy Science, The Ohio State University, and Ohio Agricultural Research and \\ Development Center, Columbus, Ohio 43210, U.S.A.
}

\begin{abstract}
Summary. Serum samples were taken from first-calf dairy heifers, twice weekly, for a period of 4 weeks, starting 2 weeks before the estimated date of parturition and continuing for 2 weeks post partum. Samples from each heifer were incubated with lymphocytes from the respective calf when possible, and from a 36-cow donor panel, in the presence of complement. Of the 31 heifers tested, 11 (35\%) raised detectable lymphocytotoxic antibodies against fetal antigens; 3 had detectable, but weak, antibody titres as early as 10 days before parturition while the others had stronger antibody reactivity which was detectable 4-12 days post partum. The titres of these post-partum antibodies peaked 4-7 days after they were first detected. Sephadex G-200 fractionation of the sample taken at 2 weeks post partum showed that 11 responding cows had antilymphocytic activity in the $\operatorname{lgG}$ fraction while 8 also had IgM antibody activity.
\end{abstract}

\section{Introduction}

The formation of antibodies directed against leukocyte antigens during or following pregnancy is a well known phenomenon. Pregnancy-induced antibodies were first detected in multiparous women and mice (van Rood, Eernisse \& van Leeuwen, 1958; Herzenberg \& Gonzales, 1962). These antibodies are generally not found in the male or the nulliparous female, but are present with increasing frequency which corresponds with parity (Payne, 1962; Terasaki, Mickey, Yamazaki \& Vredevoe, 1970; Burke \& Johansen, 1974). Serological studies indicate that these antibodies are cytotoxic and/or agglutinating in nature and are directed against paternally inherited, fetal histocompatibility antigens (Payne, 1962; Goodlin \& Herzenberg, 1964; Tongio, Berrebi, Pfeiffer \& Mayer, 1971; Nielsen \& Svejgaard, 1972; Tongio, Berrebi \& Mayer, 1972; Voisin \& Chaouat, 1974; Olson, Schlaut, Stiller \& Dossetor, 1974; Baines, Speers, Pross \& Miller, 1976). These antigens may. be expressed on placental tissues or on other fetal cells which may pose an antigenic challenge to the maternal system (Tillikainen, Schroeder \& de la Chapelle, 1974; Zilliacus et al., 1975; Carter, 1976; Goodfellow, Barnstable, Bodmer, Smary \& Crumpton, 1976). The nature of this pregnancy-related antibody response has been extensively studied in women and in laboratory animals, but is not yet well characterized in other species. Newman \& Hines (1979) have monitored leukocyte antibody response during first gestation in heifers, finding no antibodies before the last few days pre partum. The purpose of this study was to define more accurately the time and nature of this antibody response in primiparous cattle. 


\section{Materials and Methods}

Peripheral blood samples were collected in $10 \mathrm{ml}$ siliconized vacutainer tubes twice weekly from pregnant heifers, starting 2 weeks before the expected date of parturition and continuing for at least 2 weeks post partum. The serum was removed and stored at $-25^{\circ} \mathrm{C}$. A total of 234 samples was collected from 31 heifers representing 5 dairy breeds.

Antilymphocytic activity was assessed using a microdroplet lymphocytotoxicity test. The last sample taken from each animal was tested first, and if activity was detected all other samples from that animal were tested. An earlier study had indicated that virtually all heifers developing antilymphocyte antibodies would have detectable activity 2 weeks after parturition (Newman \& Hines, 1979).

Titres were determined for all samples in which activity could be detected. The class of antibody responsible for the cytotoxic activity was determined for each positive animal by fractionation on Sephadex G-200 of the sample taken at 2 weeks post partum. Effluent protein peaks were characterized with respect to immunoglobulin class and the presence or absence of lymphocytotoxic activity within them.

\section{Bovine lymphocyte separation}

Blood lymphocytes were separated from $7 \mathrm{ml}$ whole blood collected in vacutainer tubes using EDTA as the anticoagulant. Approximately $4 \mathrm{ml}$ undiluted blood was layered on $4 \mathrm{ml}$ of a Ficoll-Hypaque solution (sp. gr. 1.072) in a $16 \times 100 \mathrm{~mm}$ tube and centrifuged at $575 \mathrm{~g}$ for $40 \mathrm{~min}$. The band of lymphocytes was removed and washed free of platelets using Seligman's Balanced Salt Solution (Ohio State University Pharmacy). Washed lymphocytes were suspended in McCoy's 5A Medium (GIBCO, Grand Island, New York) and the concentration adjusted to $1-2 \times 10^{6}$ cells $/ \mathrm{ml}$.

\section{Lymphocytotoxicity test}

The lymphocytotoxicity test has been described (Newman \& Hines, 1979). Reactions were scored based on the number of dead cells, using the NIH standard scoring system (Mittal, 1978).

Each serum sample was tested against lymphocytes from a panel of 36 cows, and, if available, against lymphocytes from the calf of the cow from which the serum was drawn. All tests were run in duplicate and positive and negative controls were run with each test. The positive control consisted of an antiserum which reacted strongly with all bovine cells. Negative controls consisted of wells containing inactivated complement, wells containing a neutral serum instead of antiserum (complement control), and wells lacking both antiserum and complement (medium control).

The number of positive reactions observed for any serum sample was considered primarily indicative of the number and kind(s) of antibody specificities present. Since a primary objective was to determine the point at which strong antibodies were elicited, specificity differences were not evaluated unless they appeared to change during the response period. The strength of lymphocytotoxic antibody in a particular serum sample was determined by examining the titre end-points against reactive cells. Samples were set up in serial dilutions using neutral bovine serum as the diluent. The endpoint was classified as the last dilution at which a score of $8(\geq 80 \%$ dead cells) was obtainable in the lymphocytotoxicity test.

\section{Gel-filtration}

A $0.9 \times 50 \mathrm{~cm}$ column containing Sephadex G-200 and equilibrated with 0.01 M-phosphate-buffered saline, $\mathrm{pH} 7.4$, was used to fractionate $0.2 \mathrm{ml}$ aliquots of the reactive serum samples. After determination of the effluent protein profile by measuring ultraviolet 
absorption at $280 \mathrm{~nm}$, the fractions within the void volume peak were combined, and those within the second protein peak were combined. Both of these pools were freeze dried, and the immunoglobulin classes contained within them were evaluated by agar gel immunodiffusion assays against rabbit anti-bovine IgM and rabbit anti-bovine IgG obtained from Miles Laboratories, Elkart, Indiana. These assays indicated that the immunoglobulin in the void volume peak pool was predominantly IgM with a trace of IgG in some samples, while the only immunoglobulin detected in the second peak pool (mol. wt. $\simeq 150000$ ) was IgG.

\section{Results}

Antilymphocytic antibodies were detected in the serum of 11 of the 31 cows tested. The detailed results presented in Table 1 indicate that potent lymphocytotoxic antibody is generally detectable only in serum post partum. Calves from 17 of the 31 cows were available as lymphocyte donors and 7 were from antibody-responding cows; in all cases this maternal antibody reacted against the calf's lymphocytes. Sera from cows without detectable antibody showed no reactivity against the corresponding calf's lymphocytes.

Table 1. Serum lymphocytotoxicity reactions in primigravid Holstein (except for Cow $3=$ Brown Swiss) heifers (parturition $=$ Day 0 )

\begin{tabular}{|c|c|c|c|c|c|c|c|}
\hline Animal & $\begin{array}{c}\text { Day antibody } \\
\text { first } \\
\text { detected }\end{array}$ & $\begin{array}{c}\text { Titre of } \\
\text { first } \\
\text { detected } \\
\text { antibody* }\end{array}$ & $\begin{array}{l}\text { Highest } \\
\text { titre }^{*}\end{array}$ & $\begin{array}{l}\text { Day highest } \\
\text { titre found }\end{array}$ & $\begin{array}{l}\text { Antibody } \\
\text { class } \dagger\end{array}$ & $\begin{array}{c}\text { Day of } \\
\text { fractionated } \\
\text { sample }\end{array}$ & $\begin{array}{c}\text { Calf } \\
\text { status } \ddagger\end{array}$ \\
\hline 1 & -10 & 1 & 64 & 15 & $\begin{array}{l}\text { IgM } \\
\text { IgG }\end{array}$ & 15 & Positive \\
\hline 2 & -4 & $<1$ & 64 & 13 & $\begin{array}{l}\text { IgM } \\
\text { IgG }\end{array}$ & 13 & Positive \\
\hline 3 & 4 & 4 & 16 & 7 & IgG & 15 & Dead at birth \\
\hline 4 & 6 & 4 & 8 & 13 & $\begin{array}{l}\text { IgM } \\
\text { IgG }\end{array}$ & 13 & Positive \\
\hline 5 & 7 & 8 & 8 & 11 & $\begin{array}{l}\text { IgM } \\
\text { IgG }\end{array}$ & 14 & Positive \\
\hline 6 & 9 & 4 & 32 & 13 & $\operatorname{IgG}$ & 13 & Not tested \\
\hline 7 & 9 & 4 & 16 & 13 & $\begin{array}{l}\text { IgM } \\
\text { IgG }\end{array}$ & 13 & Dead at birth \\
\hline 8 & 10 & 8 & 16 & 13 & $\begin{array}{l}\text { IgM } \\
\text { IgG }\end{array}$ & 13 & Positive \\
\hline 9 & 10 & 1 & 2 & 14 & IgG & 14 & Positive \\
\hline 10 & 11 & 16 & 32 & 13 & $\begin{array}{l}\text { IgM } \\
\text { IgG }\end{array}$ & 13 & Not tested \\
\hline 11 & $12 \S$ & 4 & 4 & 12 & $\begin{array}{l}\text { IgM } \\
\text { IgG }\end{array}$ & 14 & Positive \\
\hline
\end{tabular}

\footnotetext{
* Expressed as reciprocal of actual titre.

† Activity found in the first Sephadex G-200 column effluent protein peak was classified as IgM and that found in the second peak as IgG.

$\ddagger$ Calves tested with maternal serum.

$\S$ Weak antibody also detected at Day -6 , but not reactive with calf's lymphocytes.
}

Low-titre antibody activity was detected in the serum of 3 heifers shortly before parturition. The pre-partum antibodies from 2 of these heifers (Nos 1 and 2) reacted with lymphocytes from their respective calves, and also with lymphocytes from the same panel cows as did the post-partum antibody. The reaction pattern, or specificity, in the serum samples from Cow 2 broadened after parturition, whereas it remained constant in the samples from Cow 1. The pre-partum antibody detected in the serum of Cow 11 did not react with her calfs lymphocytes, 
and her pre-partum and post-partum reaction patterns were dissimilar. Antibody titres ranged from $1: 1$ to $1: 64$ in reactive post-partum samples, contrasting with titres of $1: 1$ or less in reactive pre-partum samples.

Antibody reactivity was seen in the $\mathrm{IgG}$ fraction for all 11 of the responding cows while 8 of the same cows also had IgM reactivity.

\section{Discussion}

The apparent lack of high titre lymphocytotoxic antibodies in the pre-partum serum is in agreement with a previous study of cattle (Newman \& Hines, 1979). The pre-partum antibody that was detected was of low titre and was probably raised against fetal antigens in only the 2 cases in which the cow's serum reacted with her calf's lymphocytes. Lymphocytotoxic antibody that is not directed against fetal antigens has been detected in cattle previously and probably represents antibody cross-reactivity (Newman \& Hines, 1979).

These results are in apparent contrast to those obtained in studies involving primigravid women. Burke \& Johansen (1974) detected anti-lymphocyte antibody in the serum of $10 \%$ of women during first pregnancy, a rate equivalent to that found by us in cows. However, the human maternal immune system appears to be sensitized to fetal antigens as early as the second trimester (Burke \& Johansen, 1974; Youtananukorn, Matangkasombut \& Osalhanondh, 1974), whereas we detected no antibodies earlier than 10 days pre partum.

Possible reasons for the lack of high titre pre-partum antibody in primigravid heifers include suppression of the immune system during pregnancy, binding of antibody to the placenta, and failure of the maternal immune system to receive adequate amounts of antigen to raise a detectable response until late gestation or parturition. Support for the latter possibility comes from a comparison of bovine and human placental characteristics. The bovine epitheliochorial type of placenta appears to provide a more extensive barrier than does the human haemochorial type of placenta. Transplacental red cell alloimmunization is extremely rare or virtually nonexistent in cattle (Stormont, 1972).

The findings that most of the examined post-partum lymphocytotoxic antibodies were a combination of IgM and IgG classes suggests that the primary antigenic stimulus occurred early enough for the IgM to IgG switch to have been initiated, and therefore probably took place before parturition in most animals. It may well be that because of lower amounts of antigen required for secondary stimulation and increased antibody titre typical of the anamnestic response, antibodies will be detected at earlier stages of later gestations. This probability is presently being investigated.

Approved for publication as Journal Article No. 115/79 of the Ohio Agricultural Research and Development Center, Wooster, Ohio 44691.

\section{References}

Baines, M.G., Speers, E.A., Pross, H. \& Miller, K.G. (1976) Characteristics of the maternal lymphoid response of mice to paternal strain antigens induced by homologous pregnancy. Immunology 31, 363369.

Burke, J. \& Johansen, K. (1974) The formations of $\mathrm{HL}-\mathrm{A}$ antibodies in pregnancy. The antigenicity of aborted and term fetuses. J. Obstet. Gynaec. Br. Commonw. 81, 222-228.
Carter, J. (1976) Expression of maternal and paternal antigens on trophoblast. Nature, Lond. 262, 292-293.

Goodfellow, P.N., Barnstable, C.J., Bodmer, W.F., Smary, D. \& Crumpton, M.J. (1976) Expression of HL-A system antigens on placenta. Transplantation 22, 595-603.

Goodlin, R.C. \& Herzenberg, L.A. (1964) Pregnancy induced hemagglutinins to paternal $\mathrm{H}-2$ antigens in multiparous mice. Transplantation 2, 357-361. 
Herzenberg, L.A. \& Gonzales, B. (1962) Appearance of $\mathrm{H}-2$ agglutinins in outcrossed female mice. Proc. natn. Acad. Sci. U.S.A. 48, 570-573.

Mittal, K.K. (1978) Standardization of the HLA typing method and reagents. Vox Sang. 34, 58-63.

Newman, M.J. \& Hines, H.C. (1979) Production of fetally stimulated lymphocytotoxic antibodies by primiparous cows. Anim. bld Grps Biochem. Genet. 10, 87-92.

Nielsen, L.S. \& Svejgaard, A. (1972) HL-A immunization and HL-A types in pregnancy. Tissue Antigens 2, 316-327.

Olson, L., Schlaut, J., Stiller, C.R. \& Dossetor, J.B. (1974) Comparison of cytotoxic and agglutinating antibodies in the sera of parous women. Transplantation 17, 249-253.

Payne, R. (1962) The development and persistence of leukoagglutinins in parous women. Blood 19, 411424.

Stormont, C. (1972) The role of maternal effects in animal breeding: I. Passive immunity in newborn animals. J. Anim. Sci. 35, 1275-1279.

Terasakj, P.I., Mickey, M.R., Yamazaki, J.N. \& Vredevoe, D. (1970) Maternal-fetal incompatibility. Transplantation 9, 538-543.

Tillikainen, W.A., Schroeder, J. \& de la Chapelle, A.
(1974) Fetal leukocytes in the maternal circulation after delivery. Transplantation 17, 355-360.

Tongio, M.M., Berrebi, A., Pfeiffer, B. \& Mayer, \$. (1971) Serological studies on lymphocytotoxic antibodies in primiparous women. Tissue Antigens 1, 243-257.

Tongio, M.M., Berrebi, A. \& Mayer, S. (1972) A study of lymphocytotoxic antibodies in multiparous women having had at least four pregnancies. Tissue Antigens 2, 378-388.

van Rood, J.J., Eernisse, J.G. \& van Leeuwen, A. (1958) Leucocyte antibodies in sera from pregnant women. Nature, Lond. 181, 1735-1736.

Voisin, G.A. \& Chaouat, G. (1974) Demonstration, nature and properties of maternal antibody fixed on placenta and directed against paternal antigens. $J$. Reprod. Fert., Suppl. 21, 89-103.

Youtananukorn, V., Matangkasombut, P. \& Osalhanondh, V. (1974) Onset of human maternal cell-mediated immune reaction to placental antigens during the first pregnancy. Clin. exp. Immun. 16, 593-598.

Zilliacus, R., de la Chapelle, A., Schroeder, J., Tillikainen, A. Kohne, E. \& Kleihauer, E. (1975) Transplacental passage of foetal blood cells. Scand. J. Haemat. 15, 333-338.

Received 19 February 1980 